[㳫化 第 52 巻, 第 1 号, p. $31 \sim 36,1978$ ]

\title{
レドックス重合による葉緑体電子伝達系の ポリアクリルアミド固定
}

\author{
落合英夫, 柴田 均, 松尾 哲, 橋/口賢二, 湯川政雄 \\ (島根大学農学部農芸化学科)
}

昭和 52 年 8 月 22 日受理

\author{
Immobilization of Chloroplast Photosystems within Polyacrylamide Gel Formed \\ by the Redox Polymerization \\ Hideo Ochial, Hitoshi Shibata, Tetsu Matsuo, \\ Kenji HASHINOKuCHI and Masao YuKAWA \\ Laboratory of Biochemistry, College of Agriculture, \\ Shimane University, Matsue
}

\begin{abstract}
Chloroplast electron flow system was successfully immobilized inside polyacrylamide gel formed by the redox polymerization. The immobilization system consisted of acrylamide monomer $(15 \%$, final concentration), $\mathrm{N}, \mathrm{N}^{\prime}$-methylene-bisacrylamide $(0.8 \%)$, ammonium persulfate $(0.02 \%)$, ascorbate $(0.06 \%)$, bovine serum albumin $(1 \%), \mathrm{D}$-mannitol $(0.01 \%)$ and the broken chloroplasts, type $\mathrm{C}$, in $0.05 \mathrm{M}$ Tris buffer containing $0.4 \mathrm{M}$ sucrose and $0.01 \mathrm{M} \mathrm{NaCl}$ (STN buffer). Incubation of the reaction mixture at $10^{\circ} \mathrm{C}$ for $2 \mathrm{hr}$ yielded the gel keeping Photosystem I activity as $11.3 \%$ of the native chloroplasts (control) and Photosystem II activity as $11.2 \%$ of the control. The immobilized chloroplast gel retained activities of Photosystem I and Photosystem II even after being allowed to stand for several weeks in the STN buffer at $4^{\circ} \mathrm{C}$. The optimum pHs of the immobilized Photosystem I and Photosystem II were the same as those of the untreated chloroplasts: pH 8.6 for Photosystem I and pH 6.2 for Photosystem II. However, the Photosystem II activity of the gel was completely lost in 2 days on standing above $\mathrm{pH} 8$. The thermo-stabilization of Photosystem I and Photosystem II was also attained by the immobilization. Under anaerobic condition, electric current was observed on illumination onto the chloroplast photo-cell system which was composed of the gel, methyl viologen as an electron acceptor, glucose plus glucose oxidase as an oxygen dissipating system and sodium azide in the STN buffer.
\end{abstract}

(Received August 22, 1977)

\section{緒言}

葉緑体等を“Bioreactor”として用いることによって， 水より，たとえば本菜を光生化学的に生産しよらとする 企画証無公害エネルギーの開発といら立盼から現在世界 的な研究課題としてとりあげられている(1,2). しかしな がら現在までのとこる，植物生細胞より単離調製された

略号：TN緩衝液；0.01 M 程化ナトリウムを含む0.05 Mトリ又塩酸緩衝液. STN 緩衝液; TN 綬衝液比 $0.4 \mathrm{M}$ ショ糖を加光たるの. DPIP；2,6ージクロロフェノールイ ソドフェノール. DCMU；[3-(3', 4'-シクロロフェニル)] 1,1ーシメチル尿素.
葉粶体電子伝達系は一—こ礼は光化学系 I (PS-I) と光 化学系II (PS-II) とより成立っている—とり方け PSII が in vitroではきわ和不安定であるため反反応を 長時間持続させることは困難とされてきた、したがっ て, 葉緑体電子伝達系を活性の高い状態で安定であり, から取扱い易い形に固定化する方法の検討が各国で意欲 的に進められてきている. 最近 Hall らはグルタルアル デヒド固定した葉緑体と Chromatium のヒドトゲナー ゼとの混合系を用い，婔気条件下での光照射炕よって6 時間半近く連続的に水素を発生し兄たと報じている( ${ }^{(3)}$. しかし、この際のグルタルアルデとド処理された葉緑体 
の実体はやはり睤濁液であって，真の固定化された形で 実験に供されたのではなかった，一方，著者らはレドッ クス重合法を適用することによって葉緑体電子伝達系を 比較的活性の高い状熊で，から長時間の貯蔵炕耐えうる ポリアクリルアミドダルとして包括固定することに成功 し，その一部はすでに発表した(4)。ここでは固定化法の 詳細と得られた固定化葉緑体の性質，ならびにこの固定 化葉緑体を用いて水の光酸化を行い，電気エネルギーを とり出すことに成功した実験結果等についてのべる。合 わせて固定化葉緑体利用に関する問題点について考察し たい.

\section{実験材料と方法}

1. 葉緑体標品の調製葉緑体の材料としては市販 の新鮮なホウレンソウを用いた、葉軸を除いたホウレン ソウの葉を裁断してから，2 倍量の冷 STN 緩衝液 $(\mathrm{pH}$ 7.2）を加点て日本精機 HE 型ホモジナイザーにて 30 秒 間処理し，その汁液をナイロンクロスで滤過する，濾液 は冷却下 $4000 \times g$ で 10 分間遠心し，得た沈殿を毛筆で もって慎重以 STN 綏衝液に再尛濁してから， $700 \times g$ にて 5 分間遠心したそその上澄画分をもう一度ナイロン クロスにて濾過してから $4000 \times g ， 10$ 分間遠心し，得た

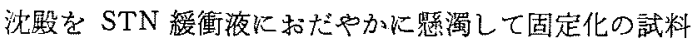
とした。この試料は主にラメラ膜画分を含もるの（タイ プC破砾葉緑体)(5)であるが，な挆他の顆粒の混在も考 えられる、しかし，細胞質内执よび葉粶体のスト口マ内 に存在する可溶性たんぱく質の混在は，ほとんどないと 見られる.な括，クロロフィルの定愠は MacKinneyの 方法によった(6).

2. 活性測定法 固定化葉緑体ダル（以下ダルと記 す）蛙よびレファレンスとしての葉緑体㲘濁液の光電子 伝達活性は，それぞれ PS-I，PS-II について求姉た。

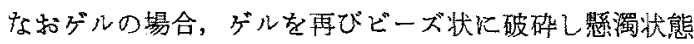
として活性測定に供した. PS-I活性の測定は Epel らの

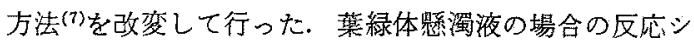
ステムは以下のようである：110 $\mu \mathrm{M}$ アスコルビン酸ナ トリウム, $17 \mu \mathrm{M}$ DPIP, $110 \mu \mathrm{M}$ メチルビオローゲン。 $110 \mu \mathrm{M}$ ナトリウムアジド， $0.67 \mu \mathrm{M}$ DCMU 拉上び葉

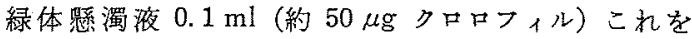

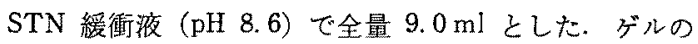
場合の反応システムは上記に括いて葉緑体憼濁液の代り に $1.2 \mathrm{~g}$ のゲルを用い，STN 緩衝液で全量 $9.0 \mathrm{ml}$ と乙
た. 反応は YSI $54 \mathrm{ARC}$ 溶存酸素計を用いて $20^{\circ} \mathrm{C}$ の佰 温下，攪找しつつある試料炕光照射 (30,000 lux) した さいの酸䋕吸収量を求め，光照射しない場合の酸菜吸収 量をブランクとして差引いだまたゲルの活性測定の場 合は、ダルを $100^{\circ} \mathrm{C}, 10$ 分間加熱処理して用いた場合の 測定値すブランク值として用いた。

PS-II 活性は䉓子受容体として $100 \mu \mathrm{M}$ DPIPを用い ゲル $0.3 \mathrm{~g}$ または葉緑体緐濁液 $0.1 \mathrm{ml}$ 亿 STN 緩衙液 (pH 7.2) を加之て全容 $3 \mathrm{ml}$ として一定時間光照射し, DPIP の光還元量を $610 \mathrm{~nm}$ での吸光度の減少の測定か ら求めた ${ }^{(8)}$ ：ダル測定の場合は反応後反応液を吸引濾過 し, 滤液の茨光度の減少犆を求めた。このさいDPIP は ポリアクリルアミドゲルに吸着されるので，光照射のみ を行なわない時の，关の滤液が示す吸光度をブランク值 とした．合るせて DPIP を電子受容体とするとル反応に よる酸素発生量の測定も行った．な叔用いた測定条件 下では，ゲルの量あるいは光照射特間はいずれるその PS-I, PS-II 活性の测定値とは直線関係にあった. グ ルコースオキシダーゼは NBC の製品（1500 単位/ダラ ム）を用いた。

\section{実 験 結 果}

\section{1. 固定化方法とその条件}

一般に醉素たんぱく質の固定化方法としては，担体結 合法，架橋法特よび包括法の 3 種がある. 包括法はさら に格子型包括法とマイクロカプセル型包括法とにわけら れる(9a). これらの方法にはそれぞれに長所短所が市る ので, 固定化されるべき対象と利用方法に心じて固定化 方法も選択されなければならない，著者らの場合固定化 される試料が，葉緑体のラメラ膜といら約 $0.5 \mu$ 程度の 大きさを持つ袋状構造体，複合醉素系であること，また エネルギー生産を目的としたシステムの構成等考慮し て，今回はポリアクリルアミトによる格子型包括法につ いて湌即した，一般にこのさいの反応試薬としては，ア クリルアミドモノマー（最終濃度 $15 \%$ ), 架橋㓮として のビスアクリルアミド（BIS，0.8\%)，重合反応促進剤 としての $\beta$-ジメチルアミフプロピオニトリル $(0.5 \%)$ および重合開始郕としての過硫酸カリ $(0.1 \%)$ を用いて いる例が多い(9b). ところで葉緑体ラメラ膜の TN 緩衝 液繋濁液に上記の試薬を 1 種類ずつ上記の濃度になるよ 亏泇之, $10^{\circ} \mathrm{C}$ で 10 分間インキュベーションした後, そのうちの一定量をとって PS-II 活性を测定したとこ 
ろそれれぞれ一檤の試薬を加えた場合には PS-II 活性に 対する阻害作用は見られなかったが，試薬を混合してラ ジル重合反応を起させた場合には，完全にその活性が 消失することが見出された。このことは，PS-II 電子伝 達系性ラジカル性重合反応汇極端に弱いことを示すす のである.

そこで著者らは電子伝撻系を保護しつつかつ重合反応 が可能な条件についているいるな角度から检討を加えた 結果, レドックス重合反応系(10)が特化優れていることが 見出されたＦig. 1 はアクリルアミドモノマー， BIS， 過硫酸アンモン, アスコルビン酸よりなるレドックス重 合反応系, さらにこれに安定化剤としてのウン血清アル ブミン (BSA) 怙上びDーマンニ゙ールを加充て葉緑体う メラ膜標品を $10^{\circ} \mathrm{C} ， 10$ 分間インキュベーションした時 のPS-II活性を示している. コントマールに比してレド ックス重合試薬を加えた場合で約 10\%，さらにBSAを 加穴た場合に約 $45 \%$ ，BSA とマンニトールを加充た場 合には約 $65 \%$ にまでその活性が保持されうることが見

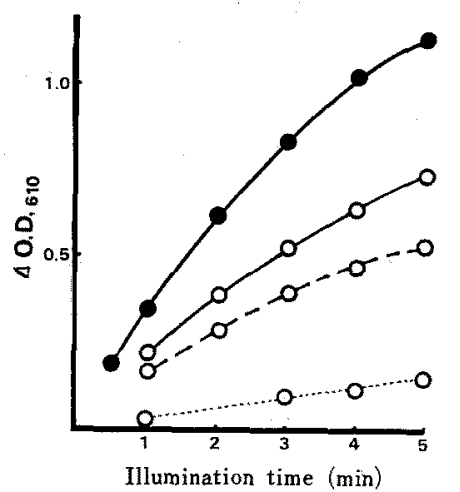

Fig. 1. Photosystem II Activities of the Spinach Chloroplast Suspension in the Presence of the Redox-polymerization Reagents: Acrylamide Monomer (15\%, final concentration), N, $\mathrm{N}^{\prime}-$ Methylene Bisacrylamide $(0.8 \%)$, Ammonium Persulfate $(0.02 \%)$, and Ascorbate $(0.02 \%)$. $O$...... 0 suspension plus the reagents (I), $0-\cdots--O$ I plus bovine serum albumin (1\%), $\mathrm{-}-\mathrm{O}$ I plus bovine serum. albumin and D-mannitol (0. $01 \%),-$ suspension plus ascorbate $(0.02$ $\%$ ) (control). The chloroplasts (700 $\mu$ g chlorophyll) were incubated for $10 \mathrm{~min}$ at $10^{\circ} \mathrm{C}$ with the reagents in the sucrose-Tris- $\mathrm{NaCl}$ buffer $(\mathrm{pH}$ $7.2,2.5 \mathrm{ml}$ in total volume). After the incubation, an aliquot $(0.1 \mathrm{ml})$ of the reaction mixture was used for Photosystem II assay as described in the text.
Table I. System for Chloroplast Immobilization

Chloroplast suspension in STN buffer $\quad 4.0 \mathrm{ml}$
$(\mathrm{pH} 7.2)^{\mathrm{a})}$

Monomers in STN buffer

37. 5\% Acrylamide monomer

$2.0 \% \mathrm{~N}, \mathrm{~N}^{\prime}-$ Methylene bisacrylamide

$2 \%$ Ascorbate in STN buffer 0.3

$1 \%$ Ammonium persulfate in STN buffer 0.2

$10 \%$ Bovine serum albumin in STN buffer 1.0

$0.5 \%$ D-Mannitol in STN buffer 0.2

STN buffer $\quad 0.3$

$10.0 \mathrm{ml}$

a) $0.05 \mathrm{M}$ Tris buffer containing $0.4 \mathrm{M}$ sucrose and $0.01 \mathrm{M} \mathrm{NaCl}$.

出されだ。

Table I はこのような検討の結果見出された葉緑体電 子伝達系固定の標準的区応組成を示するのでする。この 組成で $10^{\circ} \mathrm{C} ， 2$ 時間嫌気条件下に放固すると完全に固 定化が完了する．このようにして得られた固定化葉粶体 ゲルは日本精機 HE 型ホモジナイザーにて 10 秒間破研 処理し，直径 $1 \mathrm{~mm}$ 程度のどーズとして滤集した。この ビーズを約 100 倍量の泠 STN 緩衝液にて 3 度, のべ 1 時間呿だやかに筧找しながら洗浄した.このさい活性の 保存のためには緩衝液で充分に洗浄しておくことが必要 である.な抗このさいの活性はポリアクリルアミドダル の半透膜性のため見かけの測定值は低く表れるのである が葉緑体㯺濁液での活性に比してPS-I では $11.3 \%$ ， PS-II では 11.2\% の活性收率であった：PS-I 活性( $\mu$

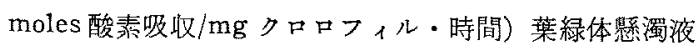
1160, ゲル 131, PS-II 活性 ( ロロフィル・時間）眯濁落 180，ダル20.1.

\section{2. 固定化葉緑体の諸性質}

Fig. 2 は得られたゲルをSTN 緩衝液中に浸漬し， $4^{\circ} \mathrm{C}$ の泠暗所に保存した場合の PS-I, PS-II 而活性の経 時的変化を垖跡した結果である. 活性は摆製㓷後の活性 を100としたときの相詨值として表わした，葉緑体䈍濁 液の PS-I 活性は一旦脱共役などのため上昇するが，2 逪間目には消失する，PS-II活性は1週間の保存で消失 する.これに対して，固定化された葉緑体の PS-I 活性 は1か月後に执いても低下は認められず，またPS-II 活 性は 2 過間で $66 \% ， 3$ 週間で $34 \%$ の相刘活性を保持し ており固定化によっていずれる大輻に定定化されらるこ とが示された，とくに PS-I 活性の安定化には注目すへ きものがあり，TN綗衝液中に保存したもののPS-I活性 
は央に 1 年络においても $22.4 \%$ の活性を保持していた。

Fig. 3 は葉緑体電子伝達系の $\mathrm{pH}$ 活性曲線である.

PS-I 活性の最適 pH は愁濁液もゲルも pH 8.6 付近に 更り，PS-II の最適 $\mathrm{pH}$ はこれも峏者とも $\mathrm{pH} 6.2$ 付近 に見出された．このことは葉緑体の䉓子伝達系という複

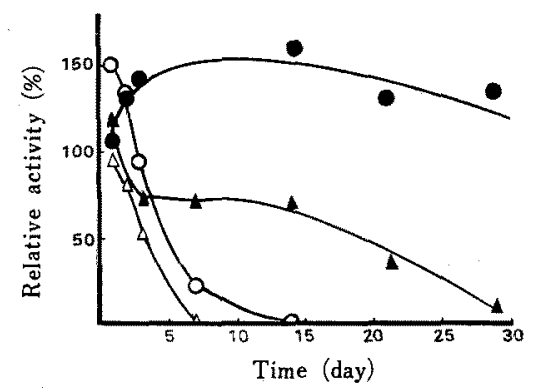

Fig. 2. Changes in the Photosystem Activities of the Chloroplast Suspension and of the Immobilized Chloroplast Gel during Storage. O-O Photosystem I activity of the suspension, - - Photosystem I activity of the gel, $\Delta-\Delta$ Photosystem II activity of the suspension, A- Photosystem II activity of the gel. Both the suspension and the gel were stored in the sucrose-Tris- $\mathrm{NaCl}$ buffer $\left(\mathrm{pH} \mathrm{7.2)}\right.$ at $4^{\circ} \mathrm{C}$, and the remaining activities of Photosystem $I$ and Photosystem II were examined. The activities are described in terms of relative value to those of freshly prepared samples (0 day).

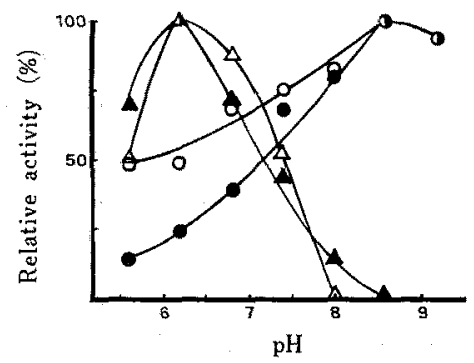

Fig. 3. pH-Activity Curves of the Chloroplast Suspension and of the Immobilized Chloroplast Gel. O-O Photosystem I activity of the suspension, - Photosystem I activity of the gel, $\triangle-\triangle$ Photosystem II activity of the suspension, A Photosystem II activity of the gel. Photosystem II activities were determined by measuring oxygen evolution through the $\mathrm{H}_{2} \mathrm{O} \longrightarrow 2,6$-dichlorophenol indophenol Hill reaction at $20^{\circ} \mathrm{C}$. The activity was expressed as relative activity $(\%)$ to that at optimum $\mathrm{pH}$. Buffer solution used : sucrose-Tris-NaCl-maleic acid.
合酔素系のポリアクリルアミド固定に怙いては，最適 $\mathrm{pH}$ の移動は起らないことを示するのである.Fig. 4 は $700 \sim 20,000 \times g$ 画分の葉緑体標品を用いて固定化した ダルに対する $\mathrm{pH}$ の効果を調べたものである。ゲルを艺 れぞれの $\mathrm{pH}$ の緩衝液中， $4^{\circ} \mathrm{C} て ゙ 3$ 日間 (PS-I)，怙よび 2 日間 (PS-II) 保存した後, これを濾取し一旦 STN 緩衙夜 (pH 7.2) で洗浄したのち活性測定した時の, 調 製直後の活性に対する相対活性值の変化を示している. PS-I 活性は保存に䟢して pHによる影響を活とんど受

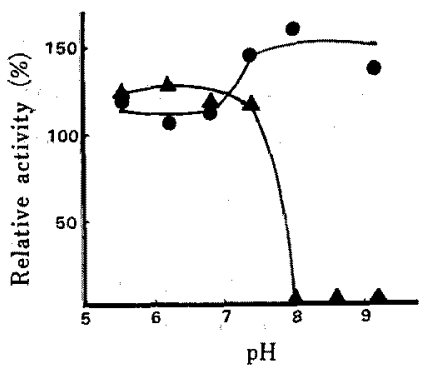

Fig. 4. pH-Stability Curves of the Immobilized Chloroplast Gel. - Photosystem I activity, -1 Photosystem II activity. The immobilized chloroplast gel was incubated in the buffer of indicated $\mathrm{pH}$ at $4^{\circ} \mathrm{C}$ for 3 days for Photosystem I assay or for 2 days for Photosystem II assay. The gel was filtered, washed with sucrose-Tris- $\mathrm{NaCl}$ buffer ( $\mathrm{pH} \mathrm{7.2)}$ and used for the assay at $20^{\circ} \mathrm{C}$. The activity is shown in $\%$ of that of freshly prepared gel measured at $\mathrm{pH}$ 7.2.

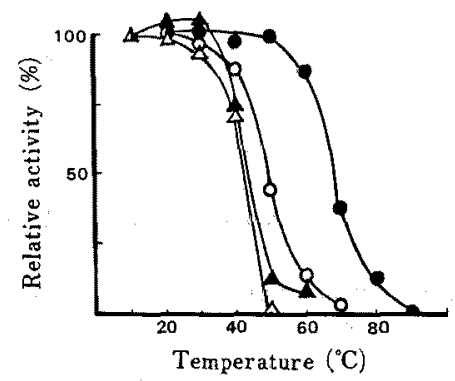

Fig. 5. Thermo-stability of the Immobilized Chloroplast Gel. O-O Photosystem I activity of the suspension, - Photosystem I activity of the gel, $\Delta-\triangle$ Photosystem II activity of the suspension, $\mathbf{\Delta - \Lambda}$ Photosystem II activity of the gel. The sample was treated: in the sucrose-Tris- $\mathrm{NaCl}$ buffer ( $\mathrm{pH} \mathrm{7.2)}$ at various temperature for $10 \mathrm{~min}$. After the treatment, the gel was allowed to stand for $10 \mathrm{~min}$ at $20^{\circ} \mathrm{C}$ and used for the assay at $\mathrm{pH}$ 7.2. 
けないが，PS-II 活性は pH 8 以上で保存すると 2 日間 で完全に失活する．この傾向は 700〜4000 ×g 画分の葉 緑体より調製したゲルでも見られている.Fig. 3, Fig. 4 の結果からゲルの保存さらに使用に際しては， $\mathrm{pH}$ 7 近辺に保つことが必要である。

Fig. 5 は熱安定性を調べた結果である.一般に葉緑体

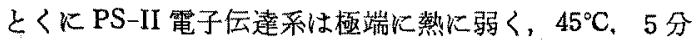
の熱処理で完全に失活する．固定化葉緑体ゲルをSTN 緩衝液 (pH 7.2) 中それぞれの温度で 10 分間熱処理し， その後 $20^{\circ} \mathrm{C}$ にもとして活性測定を行なったが，ゲルの PS-1 は $50^{\circ} \mathrm{C}, 10$ 分間の熱处理後も全く活性の低下はな く，またPS-II は同じ処理でな特 15\%の残存活性を示

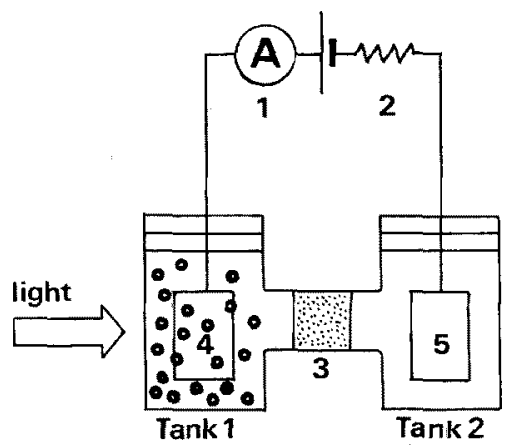

Fig. 6. Schematic Diagram of a Chloroplast Photo-cell. 1 : ammeter, 2 : external resistance, 3: diaphragm, 4 : anode (copper), 5 : cathode (copper). Tank 1 contained the immobilized chloroplast gel of $2.0 \mathrm{~g}, 0.26 \mathrm{mM}$ methyl viologen, $0.13 \mathrm{mM}$ sodium azide, $37 \mathrm{mM}$ glucose, glucose oxidase of 75 units and the sucroseTris- $\mathrm{NaCl}$ buffer ( $\mathrm{pH} \mathrm{7.2)}$ in a total volume of $7.5 \mathrm{ml}$. Tank 2 contained the same reagents except the gel. The tank 1 was illuminated with the water-filtrated light of a projector lamp $(30,0001 \mathrm{ux})$ under constant stirring.

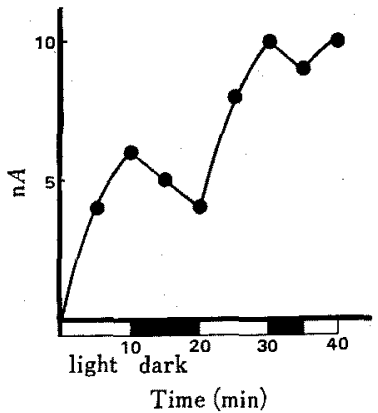

Fig. 7. Light-dependent Electric Current in the Chloroplast Photo-cell.
した.このように葉粶体電子伝達系は，ポリアクリルア ミドゲル包括固定によって熱安定性る得られることが見 出された。

な和 1 つの実験として Fig. 6 に示すよ5な電気回路 を組み，タンク1，タンク 2 Kそれぞれ Fig. 6 に示す組 成の反底液（全量 $7.5 \mathrm{ml}$ ) を入れた. グルコース，グル コースオキシダーゼの大過剩を共存させたのは反応系を 常に搬気的に保つためである：このさいダンク 1 では拉 だやかな㨨拌によって常にダルビーズが容器全体にひる がるようにして光照射した. Fig. 7 に示されているよう に光照射火依存して電流の発生することが認められた。 このさい電子伝達系の阻害剂 DCMU を共存ざせると電 流の発生は起らないし，まだルコース，グルコースオ キシダーゼ，あるいはゲルのいずれか1つを省いて子電 流の発生は見られない，このことは光照射された固定化 葉緑体によって水が光酸化され，とり出された電子が PS-II 特よび PS-I の全光化学系を通っでチルピオ口 ーダンに渡されこの還元型メキルビオローダンが婎気条 件下アノードに電子を移す回路が成立したことを示すむ のである

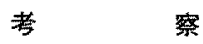

“葉緑体等による水素生産システムの確立”の検討を 進めるにあって，まず葉緑体電子伝達系の固定化に上 る安定化をいかなる方法で行らかが第一要件であるう. 事実この電子伝達系は熱，酸素などに極端に弱いために， 試みられた多くの実験結果は大抵，活性収量，保存性， 再現性などに之しい憾みがあった(11ー13)。しかし，著者 らはアスコルビン酸を重合促進剤とするアクリルアミド のレドックス量合を行光ば，低温でも反応が進行してポ リアクリルアミド固定の目的が達せられることを見出し た. 事実，こうして調製された圆定化葉緑体は保存に対 して相当に安定であり，またこのゲルへの光照射によっ て潇気条件下ではあったが，光照射に依存して電気衣 ルギーをとり出し得たことは，葉緑体を用いるェネルギ 一開発，水素生産への具体化の可能性を大きく拓く8の であらら(14).

しかし，多ちろんまだ実用化のたるには，たと价著 者らが今回の実験で用いているショ糖やBSA に代るべ き安価な試薬の開発が必要であるし，そのよらな条件下 でのレドックス重合による活性の回收率をさらに向上さ せるための研究が必要である。ラメラ膜標品にホウレン 
ソウより調製したフェレドキシン技よびフェレドキシン 一NADP+ 還元醉素を添加すると，この混合系恃 PS-II, PS-I を介して光化学的に NADP+ を還元しうることが 知られている，著者らはこの $\mathrm{H}_{2} \mathrm{O} \longrightarrow \mathrm{NADP}^{+}$還元系を 固定化しようと上述のレドックス重合反応法を適用して みたが、フェレドキシンが重合反応によって完全に失活 するために成功しなかった。したがって、NADP+ 還元 には別種の固定化方法の開発が必要である. 現在著者ら は、ポりビニルアルニールKよる包括固定によってこれ が可能で方ることを見出し研究中である。

さらに今回は葉緑体の材料として市販のホウレンソウ を用いたが，これは必ずしも適当な試料とはいえない。 すなわら，常時新鮮に大量利用できる植物村料の吟味む 是非行なわなければならない，そして最後に，連続的光 照射条件下といら特殊な環境の下での活性の保持条件の 吟味が今後進められてゆかねぱならない。

な抗このレド：クス重合反応采性，一般に活性化土ネ ルギーの低下によって低温です反応が速やか、進むとい ら利点があるので，熱汇弱い莱緑体電子伝達系の固定の みならず広く熱に不安定な酵素系あるい梳酵素の新固定 化方法としても有用であるうと考劣られる。

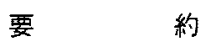

1.一般にぷリアクリルアミド固定に際して使用され る重合試薬アクリルアミドモノマー, BIS, 過硫酸カリ, ßージメチルアミノプロと゚オニトリルなどはをれぞれー 種では葉緑体電子伝達系の PS-II 活性に対してほとんど 影留を与えない，しかしこれらを混合して重合反応を起 きせると反応温度 $10^{\circ} \mathrm{C}$ においてすら完全に PS-II 活性 は消失する、しれがってこれに代るべき改良重合法を検 討した結果、アクリルアミト゚モノマー（最終濃度 15\%)，

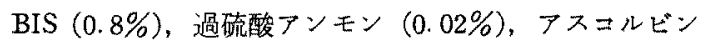
酸 $(0.06 \%)$, 牛血清アルブミン (1\%) および D-マンこ トール $(0.01 \%)$ の存在下で葉緑体標品を $10^{\circ} \mathrm{C}, 2$ 時間 処理することによって葉緑体㲘濁夜のコントロールK比 して PS-I, PS-II とも $11 \%$ 強の活性收率て固定化され ることを見出した.

2. この固定化葉緑体は STN 緩衝液 $(\mathrm{pH} \mathrm{7.2)} \mathrm{中}$ $4^{\circ} \mathrm{C}$ で暗所保存した場合 PS-I は数か月以上, PS-II は
2 週間後で $66 \% ， 3$ 週間後でる $34 \%$ その活性を保持し ていた:

3. この固定化葉緑体の最適 $\mathrm{pH}$ は馝濁液のそれと相 違ない，安定は pH 7.4 以下飞あり，とりわけ PS-II 活性は，pH 8 以上で 2 日間保存すると完全に失活す 字.

4. 固定化によってPS-II の熱安定性は若干向上し, PS-I では $50^{\circ} \mathrm{C} ， 10$ 分間の熱処理でも全く活性低下がな いまで宾定化された。

5. 婙気条件下，固定化葉緑体ピーズに光照射するこ

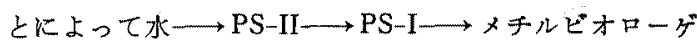
ンの光化学反応系を通しての電流発生の可動性を確認し t.

本研究は昭和 51 年度文部省科学研究蛽, 岩谷直治記 念財団よりの助成金に負らところか゚大きい。ここに記し

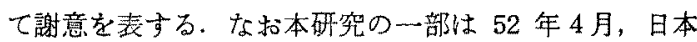
農芸化学会 52 年度大会にて発表した。

(1) M. Gibbs, A. Hollaender, B. Kok, L. O. Krampitz and A.San Pietro: "Proceedings of the Workshop on Biosolar Conversion," Indiana Univ., 1973.

(2) D. O. Hall : FEBS Letters, 64, 6 (1976).

(3) K. K. Rao, L. Rosa and D. O. Hall : Biochem. Biophys. Res. Commun., 68, 21 (1976).

(4) H. Ochiai, H. Shibata, T. Matsuo, K. Hashinokuchi and M. Yukawa: Agric. Biol. Chem., 41, 721 (1977).

(5) D. O. Hall : Nature (London), New Biol., 235, 125 (1972).

(6) G. Mac Kinney : J.Biol. Chem.,140, 315(1941).

(7) B. L. Epel and J. Neumann: Biochim. Biophys. Acta, 325, 520 (1973).

(8) H. Shibata and H. Ochiai: Agric. Biol. Chem., 37, 471 (1973).

(9) a) 干畑一郎編 : “固定化醳菜”講談社, 東京, 1975, p.9. b) idem : ibid., p.76.

(10) W. Kern : Makromol. Chem., 1, 209 (1948).

(11) L. Packer : FEBS Letters, 64, 17 (1976).

(12) M. Kitajima and W. L. Butler : Plant Physiol., 57, 746 (1976).

(13) D. Hoffmann, R. Thauer and A. Trebst : $Z$. Naturforsch., C : Biosci., 32 c, 257 (1977).

(14) T. Yagi : Proc. Natl. Acad. Sci. USA, 73, 2947 (1976). 